265:4, 475:I, 520:I0, 768:I8, 769:I2, 77I:I, 773:2I, 900:25, 981:2I, I355:20, I45I:I0, I752:II; this is the mountainous region beyond the river Tigris, situated to the south of the province of Bēt Garmay, cf. the glosses 475:I and 768:I8, where is read: حلع - miv. "in the dialect of the Highlands and that of Tirhān." This dialect is contrast-

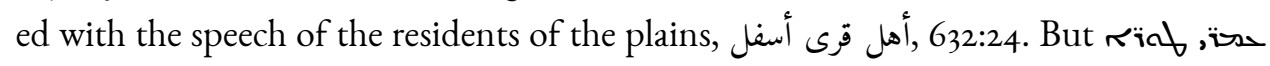
"of the mountains," 732:14, seems to designate those resident in the region of the city of Amid (Diyarbakir).

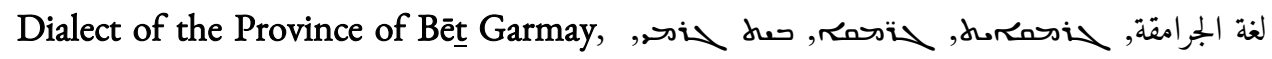
resil rel, 731:13, 741:26, 775:15, 919:17, 977:21, 1960:4. The province of Bêth Garmay, or Garama, was situated beyond the river Tigris to the south of the Lesser Zab river.

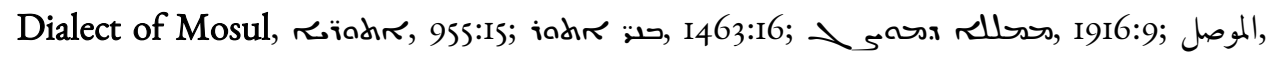
192:2.

Dialect of the Province of Diyār Rabī'a (between Mosul and Reš 'Aynā), ديار ريعة, I392:16; 1965:7.

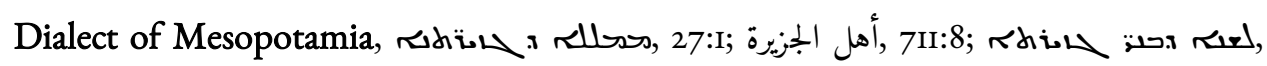

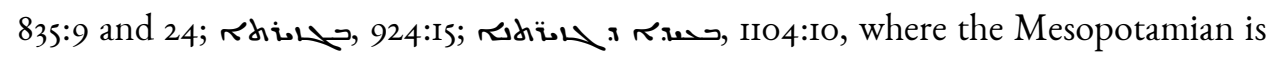
contrasted with the Babylonian.

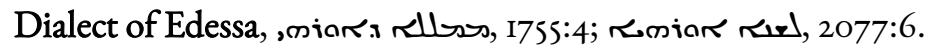

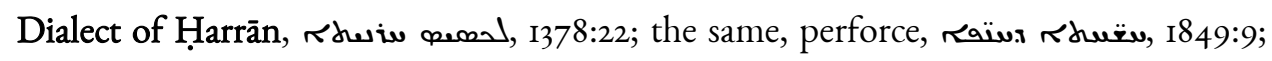
cf. The Book of the Harrānenes, p. xvii, above.

Dialect of Samosata, 575:15. لغة أهل شمشاط,

Dialect of Syria, أهل الشام, في الشام, لغة الشام, 732:6, 1917:IO, 1932:4, 1965:6.

Dialect of Palestine, 668:4.

\title{
V. DESCRIPTION OF THE MANUSCRIPTS OF THE LEXICON
}

The manuscripts that we have used in editing the lexicon are here described extensively. It will be sufficient to note others that were of no utility for us. We shall begin with the description of the manuscripts that were copied or prepared before the others. 


\section{Manuscript $\mathrm{H}$}

Manuscript Hunt. 157, now kept in the Bodeleian library at Oxford, and described by Payne Smith in his Catalogue, no. 187 , col. 617, in the following way: "A manuscript on smoothed paper in quarto, consisting of 494 folios, with Syriac and Arabic characters in plain ('Jacobite') script, very elegantly copied in the Christian year I645."

The title, embellished with red ink:

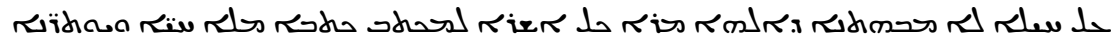

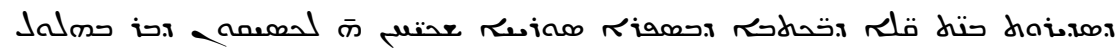
. Rims Rigo

"By the unconfounded might of God, Lord of all, I begin to write a book full of life and benefit, in which the words which occur in books are digested following the order of the Syriac alphabet, that is, the Lexicon of Bar Bahlul, the able doctor.”

There follows the Syriac preface up to iris $\precsim$ (see 2:2), then a lacuna of two pages is declared; following this, the Arabic preface occurs in full, with the following added:

$$
\begin{aligned}
& \text { وأنت يا بنيّ إيماناً بالله تعلى فاحتفاض (= فاحتفاظ) بهذا الكناب البديع ولا يخرج عن يدك }
\end{aligned}
$$

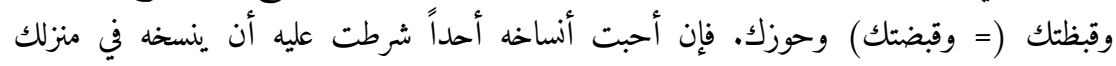

$$
\begin{aligned}
& \text { وعندك حتى لا يخرج عن ملكته إن شاء الله وهو حسبنا ونعم الوكيل. }
\end{aligned}
$$

"And you, my son, with faith in God Most High, preserve this book of wonders, and let it not leave your hands, nor your possession, nor your home. And if you desire to allow anyone to copy it, it is requisite that it he copy it in your home and in your presence so that it does not leave your possession, God willing, and He is sufficient for us and the best trustee.”

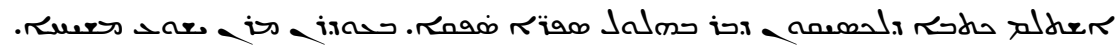

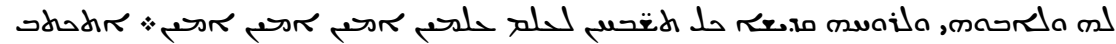

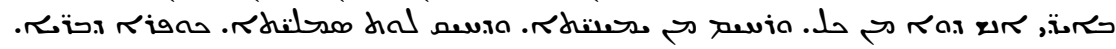

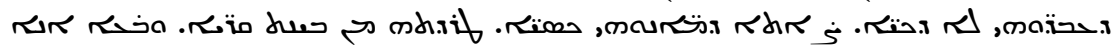

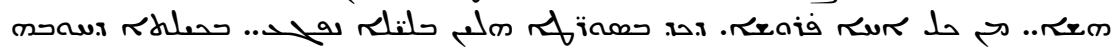

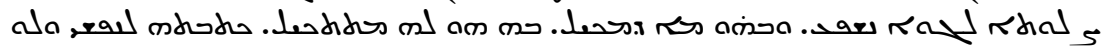
ת .

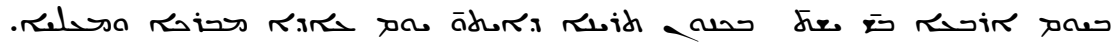

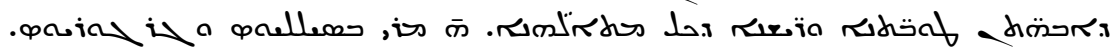

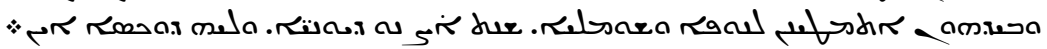

"The book of the Lexicon of Bar Bahlul the able doctor is completed by the power of our Lord Jesus Christ, to whom and to his Father and to the Holy Ghost belongs all glory for ever and ever, amen, amen, amen. It was copied by the hands of a most wretched man, far from the right hand and cast out from the left hand, filthy with 
profanity, whose works are not clean, and who was expelled from the number of the elect on account of the horrible aspect of his soul. I thus implore every wise brother, that whenever you should meet confusion in these lines, that you should pour forth with prayers in proportion to your love for the monastery, and by that same measure so shall that be measured. I wrote it for myself, not that I should be well-regarded for these crooked lines, but in order to benefit my miserable soul, this being the fourth day of the week and the sixth ${ }^{39}$ of the month of Second Qanun, being the blessed and exalted feast-day of our benevolent fathers and chiefs of all the divines, saints Basil and Gregory, with whose aid we have reached the end and the completion (of the work), in the Alexandrian year 1956. Glory to God!” Qanun II 1956 corresponds to January 1645 after the birth of Jesus Christ. ${ }^{40}$

Bernstein was unaware that this manuscript, that, intending to edit the lexicon, he occupied himself with transcribing, contains the most outstanding recension of Bar Bahlul's lexicon. ${ }^{4 I}$ Without doubt many glosses have been inserted by a 'Jacobite' reader, but the 'Nestorian' manuscripts do not lack the interpolated glosses excerpted from the 'Jacobite' recension. The Arabic glosses were written in Arabic characters, but the scribe transcribed from a Garšuni exemplar, that is, with Arabic words written in Syriac characters, as is clear from the fact that certain Arabic words remain written in Syriac characters.

\section{Manuscripts CFM}

Three exemplars of an archetype that were at one time conserved in the monastery of St. Anthony, situated in Mount Lebanon: M dates from 1597, C from 16oI, and F from 1606. The exemplar of the Maronite monastery seems to have been copied from the same old archetype from which $\mathrm{H}$ was copied; it is the same redaction, if you would exclude some added glosses, for which reason manuscripts CFM serve well to fill some of the lacunae of manuscript $H$. Manuscripts CFM faithfully exhibit the text of their Maronite archetype, the Syriac and Garšuni writings being wonderfully con-

\footnotetext{
${ }^{39} \mathrm{Sic}$; it is certain that this is the best emendation, as the feast of St. Basil was customarily celebrated on the first day of January.

$4^{\circ}$ We erred shamefully, when we wrote on page iii of the preface to the first fascicule, above: "Qanun I of the Hellenic year I596 (the month of December I284)."

${ }^{41}$ See Z. D. M. G., II, 37 I.
} 
gruent amongst them; the pronomial suffix $\_m$ is usally written $\_m$. They contain no prefaces.

\section{Manuscript $\mathrm{M}$}

Manuscript Marsh 198, now kept in the Bodleian library at Oxford and described in Payne Smith's Catalogue, no. I88 col. 623. Paper, 749 folios (0.31 x 0.20), in two columns, small but easily readable characters in the simple or 'Jacobite' script. It was sent to Jacob Golius by his brother in the year 1650 , as is learned from a note written at the beginning of the manuscript: "Sent to me out of Mount Lebanon, in the year of the Lord I650." - "Copied in Mount Lebanon by a learned man, expertly able in the Syriac language, as my brother Peter Golius, now called brother Caelestine by S. Liduina, signified to me by letter on the Calends of November, I649."

After the letter sin there reads: ro "Sergius the sinner" and, in Garšuni:

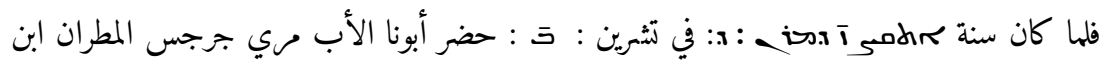

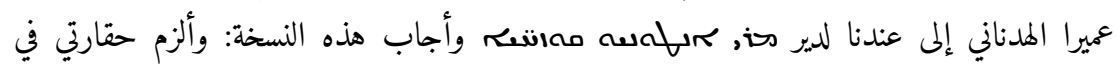

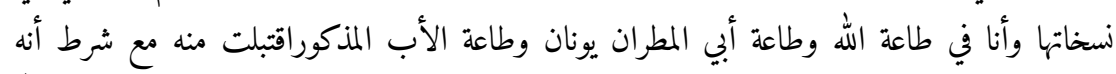

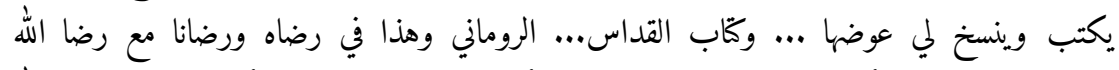

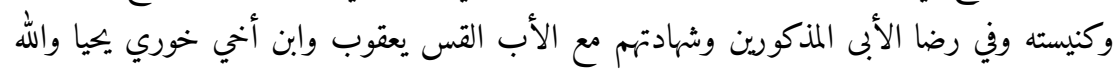

$$
\begin{aligned}
& \text { الوكيل على ما نقول أمين: كل من يوفى ندره. }
\end{aligned}
$$

"In the year of the Lord 1597, during the month of Second Tešrin, our father, Mar Gregory the Metropolitan, the son of 'Amīr of Hadnān, came into our presence in the monastery of Saint Anthony Quzhaye and arranged for this manuscript (to be written), requiring my wretchedness to copy it. I, in obedience to God and to my father the Metropolitan Yūnān, and to the aforementioned father, accepted this, on the condition that there be written and copied for me in return ${ }^{42} \ldots$ and the book of the liturgy... in Greek/Latin, and this pleased him and pleased us with the pleasure of God and the church and the pleasure of the aforementioned fathers and their witnesses with the father elder Jacob and Ibn Akhī Khūrī Yahyā, and God is Trustee for what we have said, amen. He fulfills whosoever keeps faith.”

\footnotetext{
${ }^{42}$ Here a few words have disappeared. At the end of letter àlap the same note appears, but the
} final part from قتبلت has been erased. 


\section{Manuscript C}

A manuscript kept in the library of the University of Cambridge, it consists of two volumes (one containing pages I-655, the other 656-I50I) on paper, two columns per page, with folios measuring $0.31 \times 0.21$. It was copied in the year I6or by the hand of the same Sergius ${ }^{43}$ who prepared manuscript M. At one time it formed part of Erpen's library, and after his death it was passed to the library of Cambridge. Castellus used this copy for his compendium Lexicon heptaglotton.

At the end of section alap it reads:

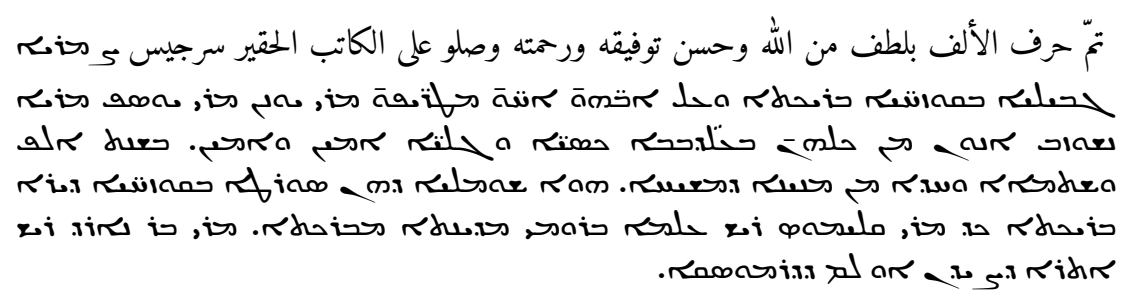

"The letter alap is completed by the grace of God, His beneficent providence, and His mercy; pray for the miserable scribe Sergius, originally of Samarra, (resident) in blessed Quzhāyē, and for the fathers and brothers, the Metropolitans Mar John and Mar Joseph, may God preserve them from all enemies hidden and manifest, amen and amen. This letter was completed in the monastery of Quzhāyē in the year I6or after the birth of Christ, with Saint Clemens (VIII) being prince of the world in Rome, city full of blessings, and Mar Bar-Narde (?) head (of the church) in the province of Saidon, or Damascus.”

There is a similar note at the end of letter $b \bar{e} \underline{t}$, the monastery of Saint Anthony of Quzhāyē is said to be in Mount Lebanon, and the name of the bishop of Syria is written برناردا. The date for this letter is 6 Šebat (February) of the year I6or.

Notes are also found following letter zayn and at the end of the first volume following letter kap. In the latter note Quzhāyē is written with the Arabic letter قوزحايه. The scribe asks for pardon from the reader errors in the book to be corrected: "I am of small understanding, the manuscript is old and (contains) a mixture of Arabic and Syriac, and all men are imperfect. Perfection is with God alone, to Whom belongs eternal glory.”

${ }^{43}$ For this Sergius, see Wright, Catalogue of the Syriac Manuscripts, $2 \mathrm{~b}$ and $3 \mathrm{a}$. 


\section{Manuscript $\mathrm{F}$}

A manuscript kept in the Laurentian library of Florence. With clear characters in the simple or 'Jacobite' script on paper, two columns per page, folios measuring $0.42 \mathrm{X}$ 0.27 , it consists of two volumes (one with 38 I folios, the other with 289 ).

At the end of the first volume, after the letter mim, it reads:

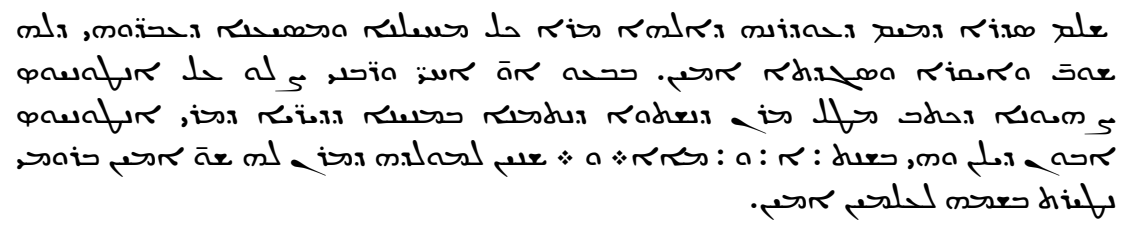

"The section of mim is complete, by the power of God the Lord of all, supporter and helper of His servants, who glorify, honor, and adore Him, amen. I implore you, oh brothers and masters, to pray for Antonius Siona, ${ }^{44}$ who wrote by (the power of) our Lord, as befits his having been one of our number among the monks of our father Saint Anthony. It was done in the year 1606 after the birth of our Lord, to whom be glory, amen. His name is ever worshipped in the city of Rome, amen.”

At the end of the last volume the following writing is found:

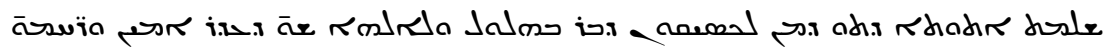

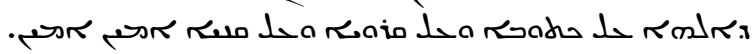

"Letter taw of Bar Bahlul's lexicon is complete, Glory to God, who aids, amen, and may the mercy of God be upon the scribe, the reader, and the owner, amen, amen.”

\section{Manuscript $\mathrm{P}$}

A Paris manuscript, kept under shelfmark 318 in the National Library; a text copied very accurately in neat 'Jacobite' characters in the year of Christ I886; it consists of 343 paper folios (0.40 x 0.28).

Title in rubric:

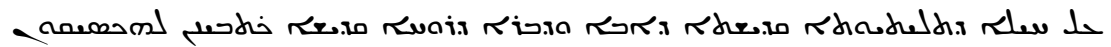

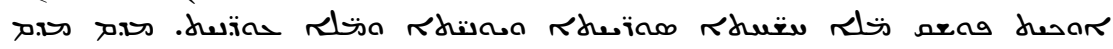

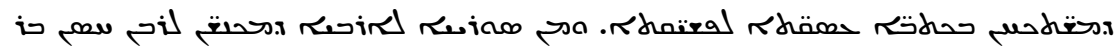

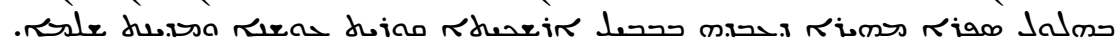

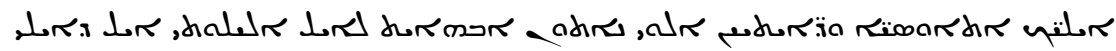

${ }^{44}$ For Antonius Siona, cf. Wright, Catal., 2b. 


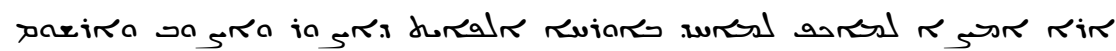
. hra.

"By the power of the Holy Trinity of the Father, the Son, and the Holy Spirit, we have written the lexicon, that is, "The Explanation of Regular Terms of Syriac and Greek and of Irregular Words such as are Found in Books Difficult to Translate,45 and (in translations) from Syriac to Arabic," collected by our master Hasan bar Bahlul, the able doctor, that he prepared in Arsacian Babylon, the seat of power and the city of peace. ${ }^{6}$ Your divine and eternal provisions, oh God, have come in a fatherly manner to aid my weakness, oh God who is my helper, ${ }^{47}$ that I should be able to proceed, following the order of the alphabet, carefully to represent, to prepare, to inscribe, and to transcribe the letter àlap."

At the end of the letter alap:

$$
\text { كمل باب الألف بعون الله على يد الفقير عبد العزيز. }
$$

Chapter alif is complete, by the aid of God to the hand of the mendicant 'Abd al'Azīz.

At the end of letter bet:

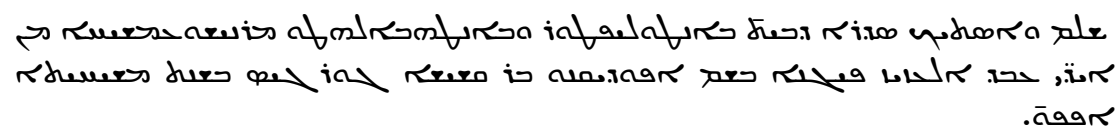

"The chapter of bet is complete and concluded by the strength and $\operatorname{aid}^{48}$ of our Lord Jesus Christ by the hands of 'Abd al-'Aziz Pigana, in the name of the subdeacon Gregory bar Qašišā in the year of Christ I886.”

After these words a few clauses of this type occur that are of no interest to reproduce.

At the end of the book it reads:

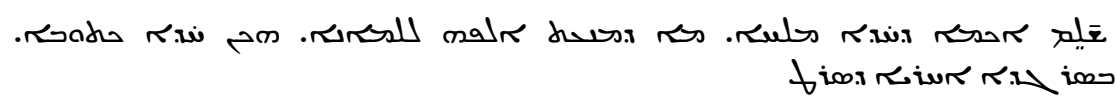

"It is complete.

\footnotetext{
${ }^{45}$ Cf. Payne Smith, Catal., columns 6or and 609.

${ }^{46}$ For the titles of Baghdad, see page xi, note I, above.

47 The scribe joins the ambiguous senses of the word $L_{\kappa} \kappa$, which we cannot render into Latin.

$4^{8}$ For this word see the lexicon of Bar Bahlul, in our edition col. 207:2 and 4 .
} 
Just as the sailor rejoices

When his ship arrives at port

So rejoices the scribe

When he copies the final line”

After this, the following verses are written in rubric:

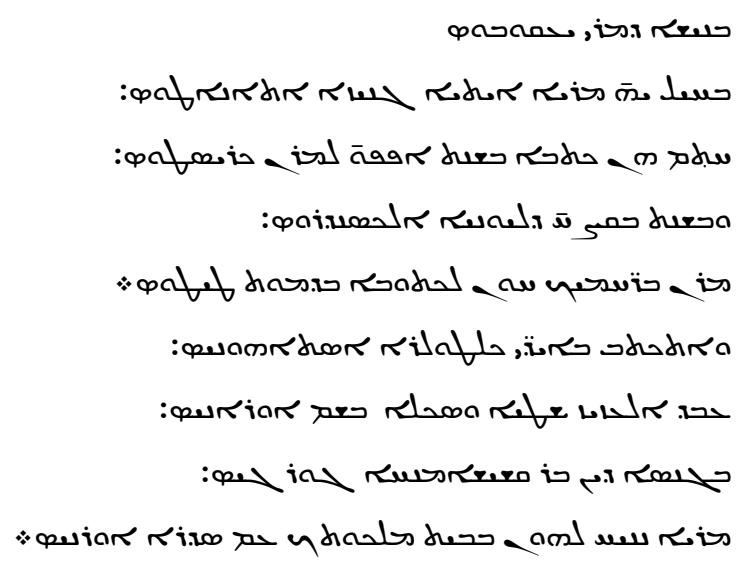

"In the meter of Saint Jacob (of Sarug).

By the power of the Lord our God, of hidden essence, immortal

This book was completed in the year 1886 of Christ our Lord

Being the year 219849 of Alexander the Greek

Oh our Lord, in your mercy, pity the scribe as you did Titus

It was written by the hands of a poor scribe

'Abd al-'Azīz, foolish and ignorant, in the name of a priest

Of the family of Bar Qašišā, Gregory, now deceased

Oh Lord, give them rest in your kingdom amidst the heavens”

$$
\begin{aligned}
& \text { سيبقا الخط مني في الكتابي. } \\
& \text { وَبِلا الكفُ في الترابي. } \\
& \text { فيا ليت مَن يقرا في كَابي. } \\
& \text { يدعو الى الخلص من العذابي. }
\end{aligned}
$$

49 I 2197 is to be preferred, see above. 
"My writing will remain in this book

After my hands have become dust

So let ye who read my book

Pray that I be delivered from torment”

In Garšuni, that is, in Syriac letters:

قد كمل ونجز هذا الكتاب الذي هو كتاب الاكسيقون سرياني تاليف ربان حسن ابن بهلول العالم

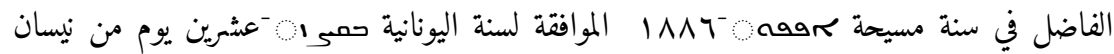

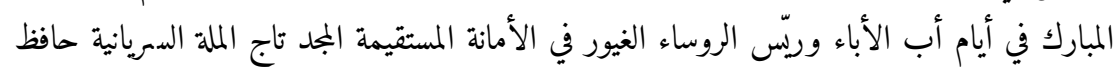

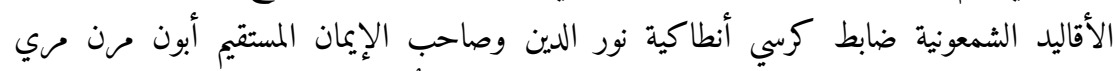

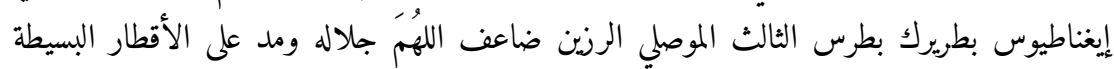

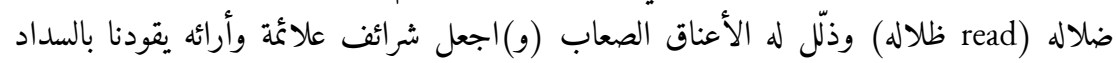

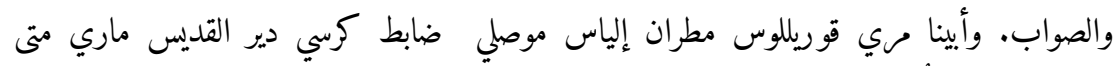

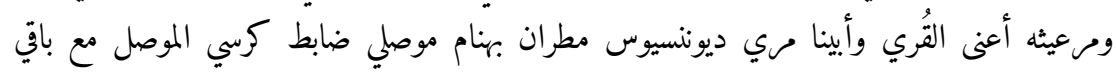

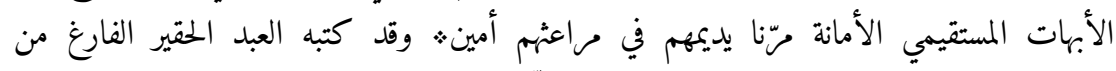

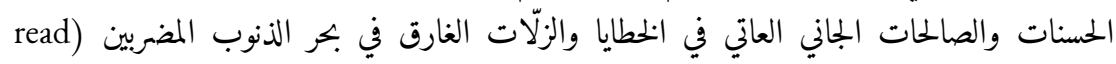

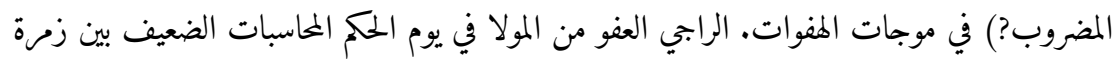

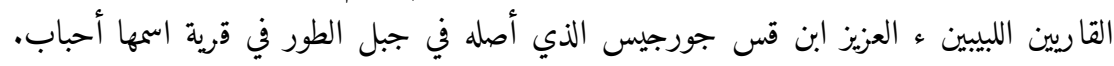

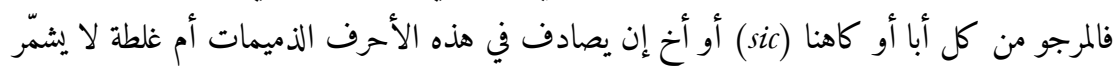

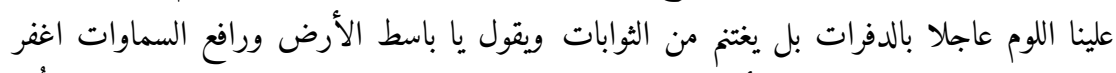

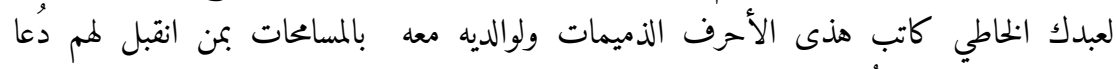

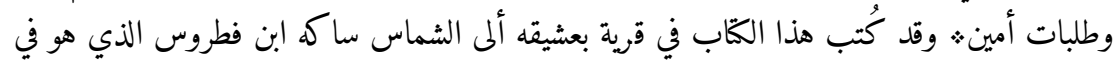

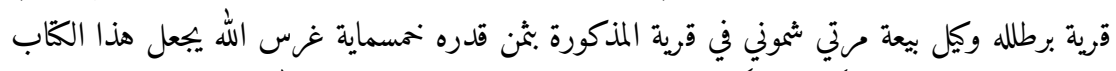

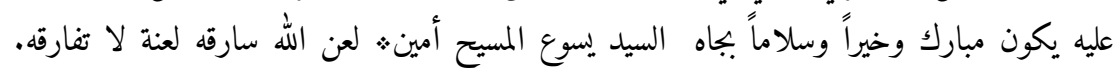

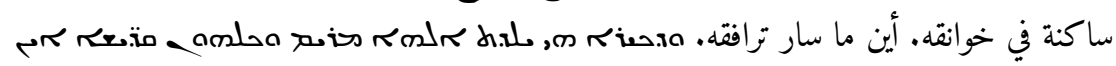

סחד

"This book, being the Syriac lexicon authored by our master Hasan bar Bahlul, the able doctor, was completed and fulfilled in the Christian year I884, which corresponds to the Hellenic year 2197, on the twentieth day of Nisann the Blessed, in the days of the father of fathers and prince of princes, fervent in orthodox faith, the distinguished, the crown of the Syrian nation, keeper of the Petrine keys, seated on the throne of Antioch, light of the religion, companion of the orthodox faith, our father and master Mar Ignatius, as patriarch named Peter III of Mosul, the venera- 
ble-may God increase his majesty, spread his shade over the regions of the Earth, abase before him obstinate necks, and ordain that the nobilities of his signs and judgments direct us to the right and just (way) —, in the time of our father, Mar Cyrillus, called metropolitan Elias of Mosul, seated on the throne of the monastery of Saint Matthew and its diocese (meaning its environs), and in the time of our father Mar Dionysios, called metropolitan Behnām of Mosul, seated on the throne of Mosul with the remains of the righteous and faithful fathers; may our Lord abide them in their dioceses, amen.

It was written by a miserable slave, vacant of good qualities and righteous deeds, a sinner refractory in offending and error, drowned in the sea of sin, buffeted by waves of faults, who desires to be forgiven on the day of judgment and accounts, the weakest of the body of intelligent readers, 'Abd al-'Azīz, the son of Gregory the Elder, who is of a village called Iḥbāb ${ }^{50}$ in Ṭūr 'Abdīn. Whosoever, whether father, priest, or brother, happens to find an error in these reprehensible pages, let him not hasten to cast the stench of blame upon us, but rather let him enrich himself from the irreproachable, SI $^{\mathrm{I}}$ saying 'Oh you who made the Earth extensive and exalted the Heavens, forgive and pardon your sinning servant who copied these reprehensible pages, and his parents with him, that they might remain among those from whom prayer and entreaties will be accepted, amen.'

This book was written in the village of Ba'shīqa for Sākah ibn Pețrūs the deacon, to whom is entrusted the church of Saint Shamon in the village of Bartella, ${ }^{22}$ for the price of 500 piasters. May God guard this book for him, and may it be blessed, sound, and complete in honor of Jesus Christ our Lord, amen. May God curse the one who steals it with an unbroken curse, and may his throat be silenced wheresoever he takes it. In commemoration of the Mother of God and all of the saints, amen.”

Manuscript P shows the same recension as that of manuscripts SSs, but it contains many additional glosses. At the end of letter ālap, it has seventeen columns of verbs beginning in dr<; at the end of letter mim, it has 2I columns of verbs beginning with

\footnotetext{
${ }^{\circ}$ Haebāb according to Prym and Socin, Tur Abdin, vii.

SI Perhaps صواب =ثوب?

${ }^{2}$ For the villages of Ba'shīqa and Barțella in the region of TTur 'Abdin, see Prym and Socin, Tur Abdin, v.
} 
גs; at the end of letter nun, it has seven columns of verbs beginning with du; for the following letters, see our edition.

\section{Manuscript S}

A manuscript on paper, 34I folios (0.33 x 0.23), two columns per page, written in 1796 anno Domini in Syriac and Garšuni. Previously having formed a part of the library of the distinguished professor Albert Socin, it is now kept in the library of the German Oriental Society (Die deutsche morgenländische Gesellschaft). It shows the same text as manuscript $S$ s, but many foreign glosses have been included.

It begins with an Arabic note, which mentions the name of the master of students 'Abd al-Ahad ibn al-Muqaddisī Elias.

At the end of letter têt

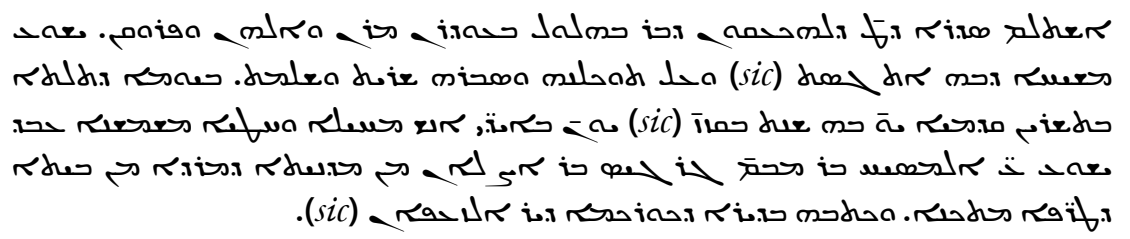

"The section of têt of Bar Bahlul's lexicon is complete, by the power of our Lord, our God and our Savior, Jesus Christ, with whom I have taken refuge and upon whose trust and whose hope I begin and end, on the third feast and sixteenth day of First Tešrin (October) of the Hellenic year 2107 (1795 after the birth of Jesus Christ), by the hand of a weak and sinful man, 'Abdišo' or 'Abd al-Massịh, son of George bar Așlān the deacon, originally of the city of Mardin, from the house of Folios (tarpēe). It was written in the monastery of Kurkāmā, or Dayr al-Zafarān.”

In the margin, in Arabic letters:

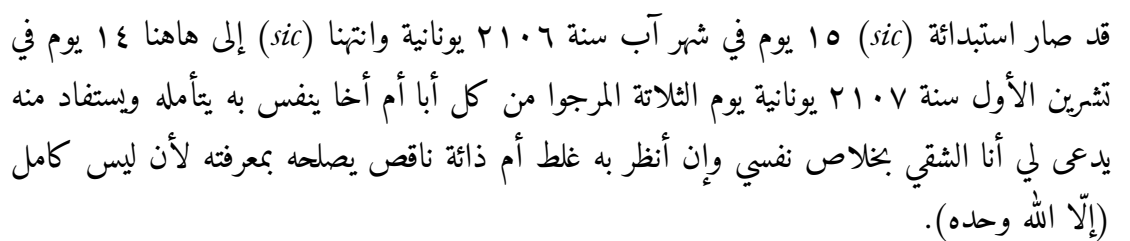

"It was begun on the $15^{\text {th }}$ day of the month of $\bar{A} b$ (August) of the Hellenic year 2106 (1795 after the birth of Jesus Christ), and we have now reached this the $14^{\text {th }}$ day and third feast of First Tešrin in the year 2107. It is to be hoped, from any father or brother who may desire to consider it or make use of it, that he would pray for me, I who am miserable, for the salvation of my soul, and if he should see in it a mistake 
or error, that he correct it according to his knowledge, for there is none perfect save God alone.”

At the end of the manuscript, in Syriac letters:

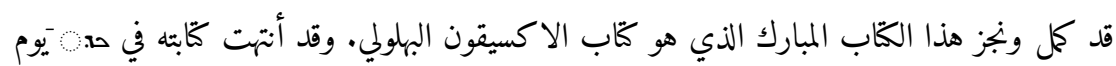

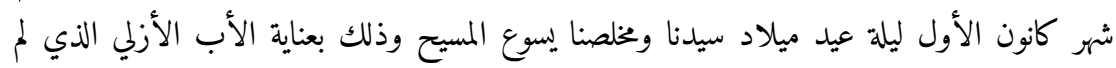

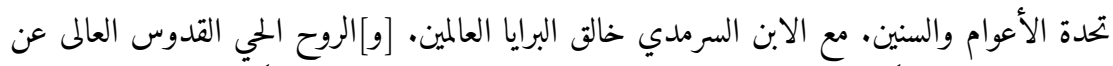

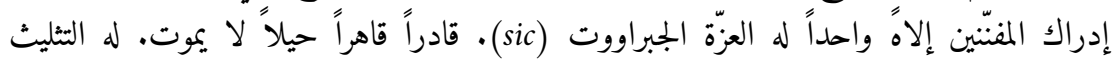

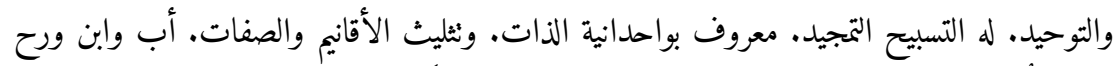

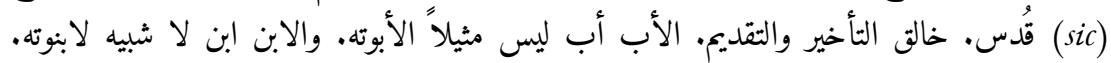

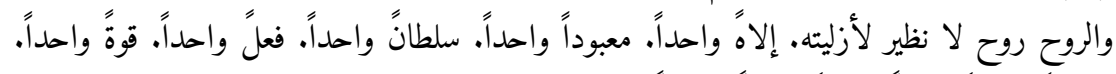

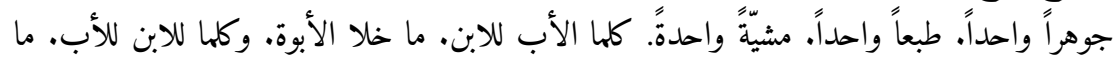

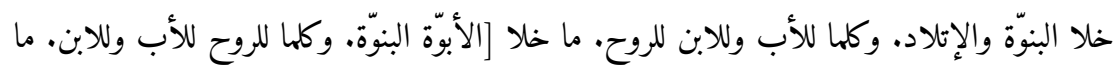

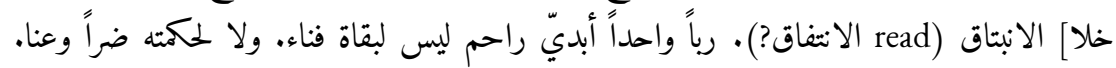

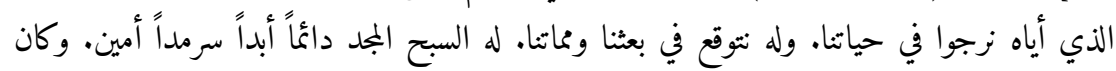

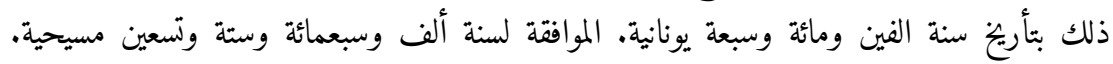

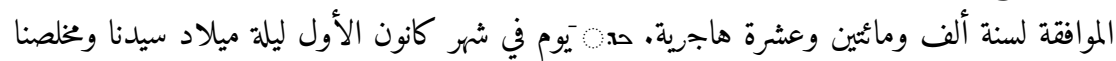

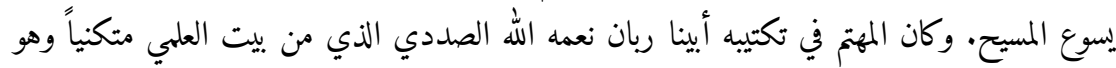

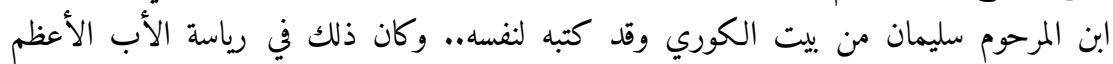

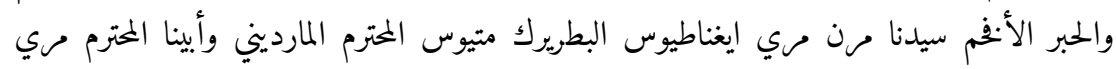

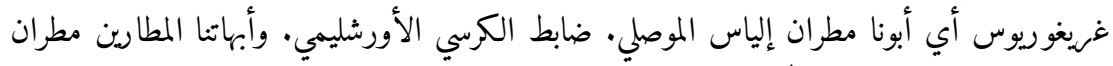

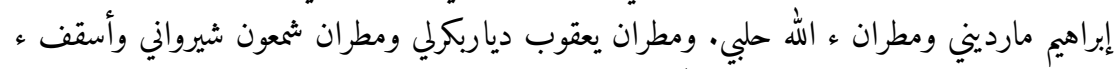

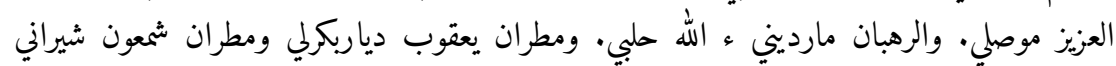

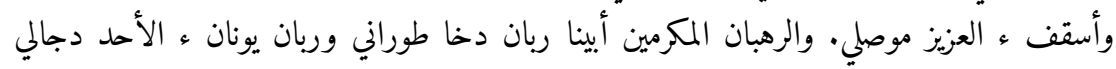

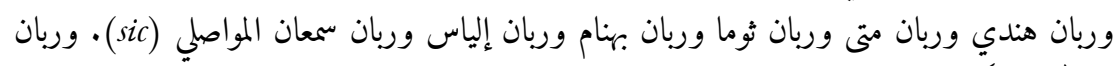

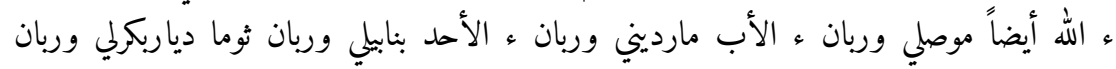

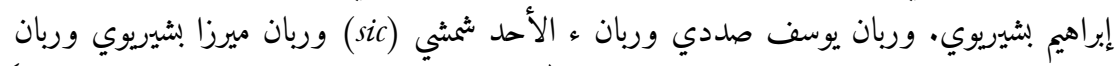

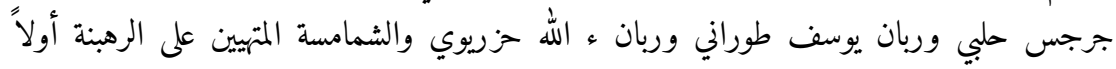

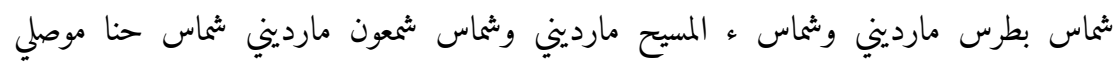

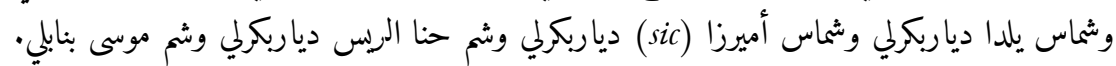

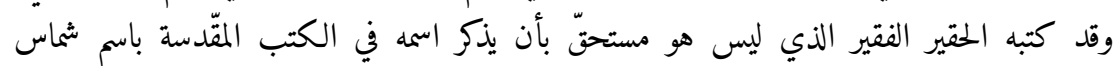

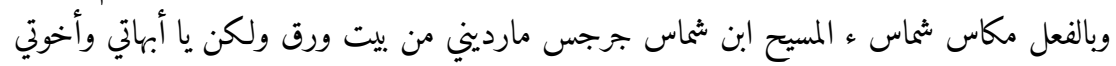

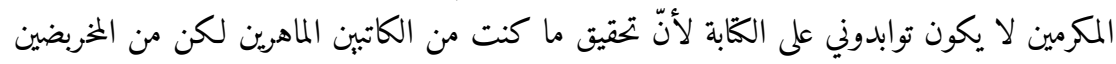




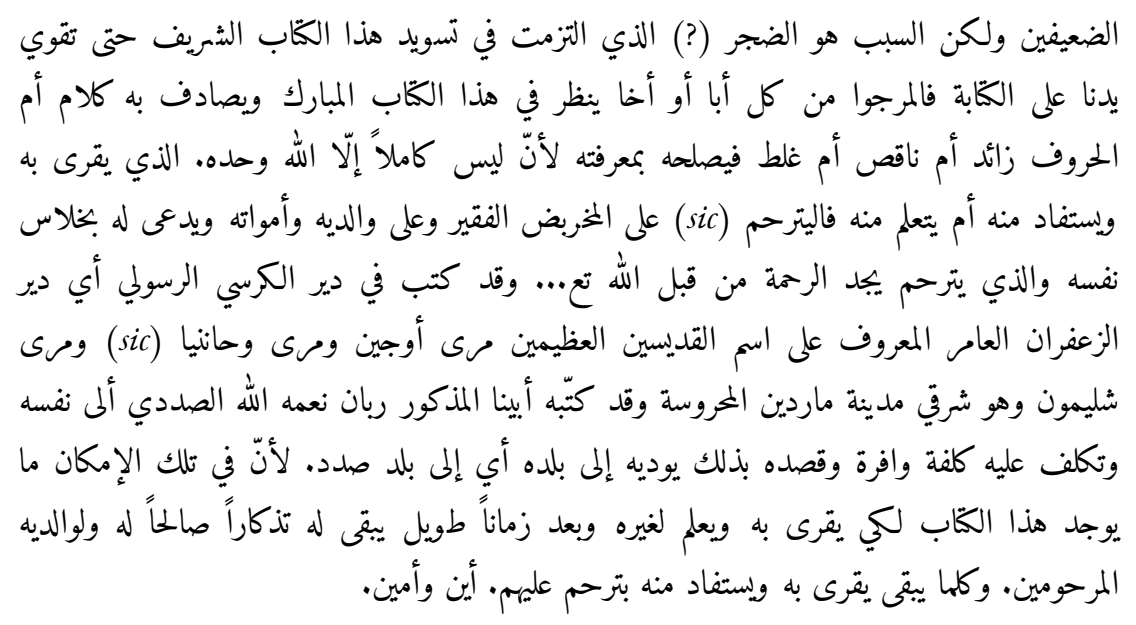

"This blessed book, being the book of the Bahluli lexicon, is completed and fulfilled. I have finished it on the $14^{\text {th }}$ day of the month of First Kānūn, on the eve of the feast of the birth of our Lord and Savior Jesus Christ, by the aid of the eternal Father, whom ages and years do not limit, with the eternal Son, creator of the creatures of the worlds, and the living Holy Ghost, exalted beyond the understanding of all the adepts, one God, to whom belongs majesty and sovereignty, powerful, overwhelming, and mighty, who does not die, who is proclaimed three and one, to whom belongs glory and magnification, known by the unity of the essence and the trinity of hypostases and attributes, Father, Son, and Holy Ghost, creator of the last and the first. Father, without there being anything similar to Him in His fatherhood, Son, without there being anything like to Him in His sonhood, and Spirit, a spirit without there being anyone to observe His eternity, one God, one worshipped, one sovereign, one doer, one power, one essence, one nature, one willer. The relation between the Father and Son is never devoid of fatherhood, the relation between the Son and the Father is never devoid of sonhood and begetting, the relation of the Father and the Son to the Spirit is never devoid of fatherhood and sonhood, and the relation of the Spirit to the Father and the Son is never devoid of procession. One eternal, merciful Lord, whose everlastingness is never extinguished, whose wisdom requires no effort nor labor, for whose help in our lives we hope, upon whom we rely in our life and our death, and to whom belongs unending, everlasting, and eternal glory and magnification.

This was done in the Hellenic year 2107, corresponding to the Christian year 1796, and corresponding to year I2IO of the Hijra, on the $14^{\text {th }}$ day of the month of First Kānūn on the eve of the feast of the birth of our Lord and Savior Jesus Christ. The 
one who asked that it be written was our father and master, may God bless him, alȘadadī, named for the house of al-'Alīmī, son of the deceased Suleymān of the house of al-Kūrī; he asked that it be written for himself. This was done under the leadership of the great father and most magnificent bishop, our lord and master Mar Ignatios the Patriarch, who is the venerable Matthew of Mardin, and that of our venerable father Mar Gregory, who is our father metropolitan Elias of Mosul, seated on the throne of Jerusalem, and during the time of our metropolitan fathers, metropolitan Abraham of Mardin, metropolitan 'Abdullah of Aleppo, metropolitan Jacob of Diyarbakir, metropolitan Simeon of Širwān, and bishop 'Abd al-'Azīz of Mosul, and that of the blessed monks, our fathers, Rabbān Denhā of Ṭur 'Abdīn, Rabbān Yūnān of Ṭur 'Abdīn, Rabbān 'Abd al-Aḥad of Dajāl, Rabbān Hindī, Rabbān Mattai, Rabbān Thomā, Rabbān Behnām, Rabbān Elias, Rabbān Simeon of Mosul, Rabbān 'Abdullah, also of Mosul, Rabbān 'Abd al-Ab of Mardin, Rabbān 'Abd al-Aḥad of Banābil, Rabbān Thomā of Diyarbakir, Rabbān Abraham of Bušīrayw, Rabbān Joseph of Șadad, Rabbān 'Abd al-Ahad of Šamš, Rabbān Mīrzā of Bušīrayw, Rabbān George of Aleppo, Rabbān Joseph of Ṭur 'Abdīn, and Rabbān 'Abdullah of Hazarayw, and that of the deacons, who are being prepared for the monastic life, deacon Peter of Mardin, deacon 'Abd al-Massīh of Mardin, deacon Simeon of Mardin, deacon Hannā of Mosul, deacon Yaldā of Diyarbakir, deacon Mīrzā of Diyarbakir, deacon Ḥannā al-Ra'īs of Diyarbakir, and deacon Moses of Banābil.

It was written by a miserable pauper, undeserving to have his name mentioned in the Holy Books, deacon in name but in reality a tax-collector, deacon 'Abd alMassìn, son of George the deacon, of Mardin, of the house of Leaves. Oh my blessed fathers and brothers, would that you would not be angry with me concerning the way in which it is written, for in reality I am not an expert scribe, but rather a foolish corrupter, the cause of that being my weakness (al-dajr), on account of which I found it necessary to draft a copy of this illustrious work, though our hand feared to write it. It is to be hoped, then, from any father and brother who looks upon this blessed book and chances upon a superfluous, lacking, or mistaken word or letter, that he rectify it according to his understanding, for there is none perfect save God alone. May the one who reads this book and benefits or learns from it pray for mercy upon this corrupting pauper and his ancestors with a sincere soul, and may the one who prays for mercy himself find mercy from God the most high. 
It was written in the monastery of the apostolic throne, which is Dayr al-Zacfarān the prosperous, famous for the names of its majestic saints Mar Eugenius, Mar Hānanī, and Mar Solomon, lying to the east of the wealthy city of Mardin. Our renowned father Rabbān al-Ṣadadī, may God bless him, caused it to be written, taking upon himself great expense, with the intention of removing it to his homeland, that is, to the land of Șadad, where this book is not to be found, that he might read it and teach it to others, and that it might be for a long time a blessed memorial to him and his deceased parents, may God have mercy upon them. May mercy be given unto them whenever anyone reads it and benefits from it, amen.”

From these clauses it is clear that this manuscript belongs not with the 'Nestorian' manuscripts, as we mistakenly said in the preface to the first fascicule, p. iii, but rather belongs with the 'Jacobite' manuscripts.

\section{Manuscript $S s$}

A manuscript of polished paper, with 248 folios (0.25 x 0.16), written in Syriac and Arabic, containing the first volume of the lexicon extending from alap to tẹt. Written in an old hand up to the words مشi (for us, column 147:7); the text following is renewed in a more recent hand from an archetype which lacks the Arabic glosses, but these latter glosses are added from another manuscript at the ends of lines or in the margins. It contains the same Syriac and Arabic text as manuscript S. Forming at one time a part of the library of professor Albert Socin, it is now kept in the library of the German Oriental Society.

At the end of the volume it reads:

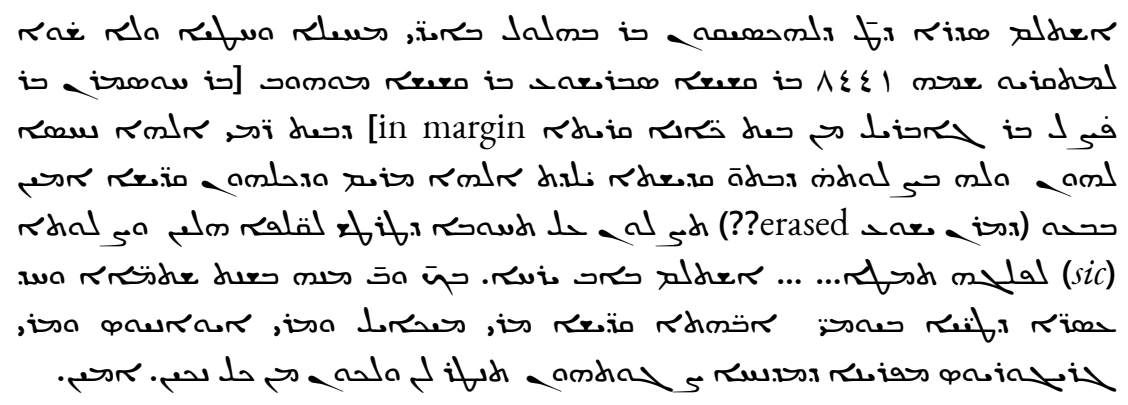

"Section tet te of the lexicon of Bar Bahlul has been completed by the hands of a weak sinner unworthy to have his name mentioned, Joseph, son of the elder Sabrišoc, son of the elder Mawhub, son of Husmarān, son of Faḍl, son of Gabriel, of the village of Bet Kene, of the house of Ramay. May God forgive them and him by the prayer of the holy virgin Mary, mother of God, and that of all the saints, amen. I implore 
thee, oh lord Jesus Christ, to pray for this fool, blackened with these sins, and pray for the one who, approaching, shares (in it)... ... It was completed in the month of $\overline{\mathrm{A}} \mathrm{b}$ (August), on the twenty-second day, in the $6 \mathrm{II}^{\text {th }}$ year of the Arabs, in the time of the holy fathers Mar Michael, Mar John, and Mar Gregory, Maphrian of the Orient, may their prayer preserve you and us from all evil, amen.”

Following, in Syriac characters:

$$
\begin{aligned}
& \text { هذا ما بعنا هوده الكتب ثلاثة وهم كتاب الاكسيقون ابن بهلول إلى مقدسي يوسفشاه النسطوري }
\end{aligned}
$$

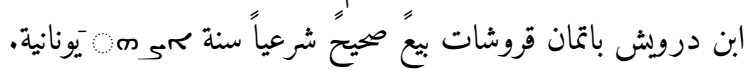

"We sold these three volumes, which contain the lexicon of Ibn Bahlul, to Muqaddasī Yūsufšah ibn Darwī̌s the 'Nestorian', for eight piasters, a sound and legitimate transaction, in the Hellenic year 1905.”

Next, written in rubricked Arabic characters:

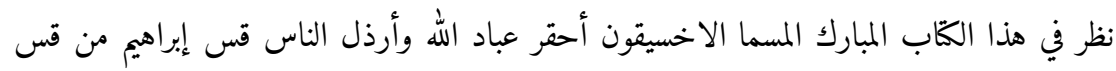

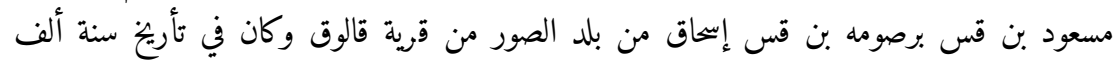

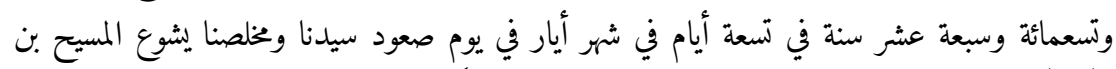

$$
\begin{aligned}
& \text { الله الله يرحم الذي كتب هذا الكّاب ولنا والذي يقرأ أيضاً ويترحم أمين. }
\end{aligned}
$$

"This blessed book, called the lexicon, was inspected by Abraham the elder, a miserable slave of God and the most wretched of humanity, son of elder Mas'ūd, son of elder Bar-Ṣawma, son of elder Ishāa, of the village of Qālūq in the land of Tyre. This was in the year 1917 on the ninth day of the month of Iyār, on the day of the Ascension of our lord and savior Jesus Christ the Son of God, may God have mercy upon and be merciful to the one who copied this book, upon us, and upon the one who reads as well, amen.”

It is now clear that this manuscript is to be counted among the 'Jacobite' manuscripts, and not among the 'Nestorian'.

\section{Manuscript $\mathrm{R}$}

A manuscript on paper in four volumes, now kept in the Borgian Museum of Rome, with the shelfmarks $\mathrm{H}$. III I-4. The volumes were written neither by a single hand nor at a single time, but rather seem to be dispersed parts of 'Nestorian' and 'Jacobite' originals, which were later made into one collection. In these volumes the Arabic words are written in Arabic characters. 
The first volume, written on folios scarcely countable (measuring $0.22 \times 0.16$ ), defective at the beginning and end, worm-eaten, carries no date; it may be referred to the thirteenth or fourteenth century. The final part of the Syriac preface and the entirety of the Arabic preface are extant. The names of the authors to whom Bar Bahlul refers (in the text) are almost always rubricked. It begins with letter allap and continues through letter dālet. It lacks many glosses that are present in other manuscripts; some lines have been lost due to moisture.

The title of letter allap expresses the following:

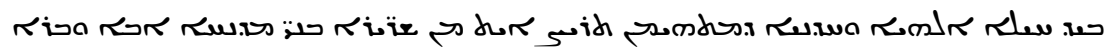

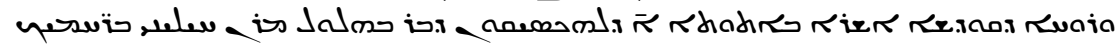
אחדות.

"By the power divine and unique, in which the righteous sons of the East put their trust, Father, Son, and Holy Ghost, I begin letter àlap of the lexicon of Bar Bahlul.

Oh Lord, strengthen me and have mercy upon me, amen.”

At the end of that letter:

$$
\text { تمّ حرف الألف بلطف الله وحسن توفيقه ورحته وقوبل به أيضاً. }
$$

"Letter alap is completed by the kindness of God, His benevolent provision, and His mercy, and repaid by Him as well.””

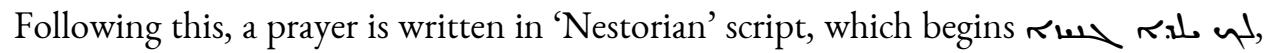
"a secret was born unto you," then:

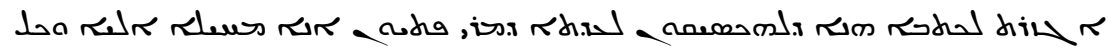

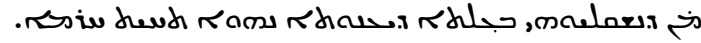

"I, infirm Elias, grant this book of the lexicon to the church of Mar Petion, and let whosoever takes it due to greed be anathema."

The second volume is written on folios scarcely countable (0.25 x 0.17) in very thick and somewhat more modern letters; the names of the authors cited by Bar Bahlul are written in black ink. It begins with letter hẹt and continues up to the word id of letter kap. Many glosses have been added by another, yet still old, hand. The folio containing the words rhonew-o $\downarrow$ was at one time separated from the rest; it is found five folios away from its proper place (after $\sim$ iinw).

The beginning reads

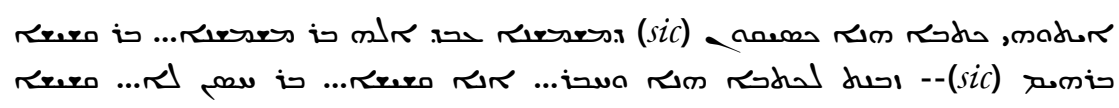




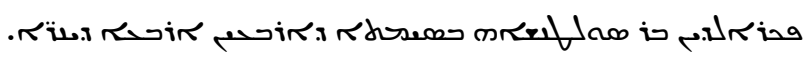

"This book of the lexicon belongs to deacon 'Abdullah, son of the deacon... ... son of elder Abraham, I sold this book and a friend... ... I the elder... ... Bar Hasan did not... ... elder Fakhr al-Dīn bar Sulțānšāh for the price of forty-four dinars.”

At the end of the letter kap, in 'Nestorian' characters:

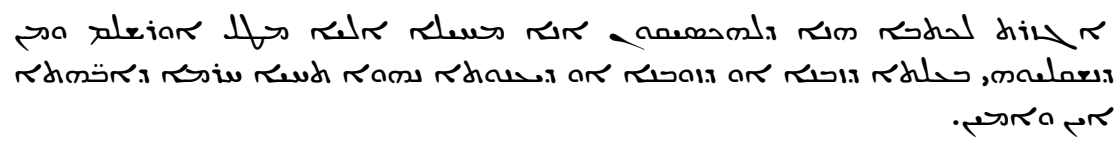

"I, infirm Elias, bestow this book of the lexicon for the sake of Jerusalem, and let whosoever takes it in order to sell it, or in order that it be sold, or out of greed be anathema to the fathers, amen.”

Following, in Arabic characters:

$$
\text { • نجز الجزو الثاني من اللهكسيقون حسين بن البهلول الكاتب الطيرهاني الحمد لله أولاً وآخيراً }
$$

"The second part of the lexicon of Hussain (sic) ibn Bahlūl, the scholar of Ṭìrhān is complete, praise be to God at the first and the last.”

Upon the final page, a librarian has attached a fragment of paper, upon which is written: “Questo codice è scritto l'anno dell' Egira 63I ('this manuscript was written in the year 63I of the Hijra')" (I233-I234 after the birth of Jesus Christ). This date may have been noted in Arabic on a now-lost folio of the manuscript.

The third volume, containing 235 folios ( $0.25 \times 0.16$ ), at one time seems to have been the second volume of manuscript $S s$, described above. It shows the same scribal hand and calligraphy, both are written on polished paper, and both have the same yellowish ink. As in manuscript $S s$, missing folios have been re-copied in a more recent hand and restored; see among others the folio numbered 339. While the other volumes

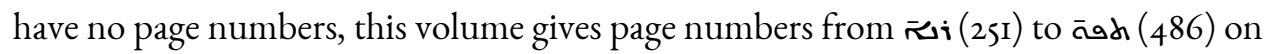
the recto of the folios. The folios of manuscript $S_{s}$ are indicated in the same way, to number 248. It begins with the letter yod and continues to the end of the letter semkat. Whatever the case may be, it contains a different recension from that of the second volume, as is clear from (comparing) the sections for the letters yod and kap, which occur in each of the two volumes.

At the end of the letter kap there is written in 'Nestorian' characters:

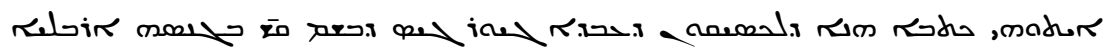


"This book of the lexicon belongs to George the slave (of God), named elder, of an Arbelan family, now of Amid.”

At the end of letter mim:

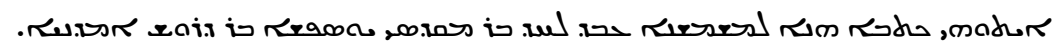

"This book belongs to the deacon 'Abd al-Ahad bar Muqaddasī Yūsufšāh bar Darwiš of Amid." Compare the note in manuscript $S$ s, cited above, p. xxxv, which states that three volumes of the lexicon were sold to the 'Nestorian' Muqaddasī Yūsufšāh bar Darwiš. Comparing these notes to one another makes again the argument that the third volume of manuscript $\mathrm{R}$ was once a volume of manuscript $\mathrm{S}$ s.

The fourth volume was written in the year 1508 on unnumbered paper folios (0.25 x 0.17) in a 'Jacobite' hand. It begins with letter 'ayn and concludes after the end of letter taw. The glosses of letters 'ayn and $p \bar{e}$ are written continually, without distinguishing space; in the subsequent letters, each of the glosses has its own distinct place. Letter șāde contains many abbreviations.

In the margin of the recto of the final folio it reads:

$$
\text { تمّ حرف التاء ومع تمامة نجز كناب لكسيقون وهو لحسين بن بهلول وذلك في أواخ شهر أذار شنه } 1 \text { (sic) }
$$

"Letter $t \vec{a}$ is complete, and with its completion the book of the lexicon of Hussain (sic) ibn Bahlūl is finished, in the final days of the month of Adar (March) of the Hellenic year [I] 819 (I508 after Jesus Christ), and the glory is God's, amen.”

On the verso of the final folio:

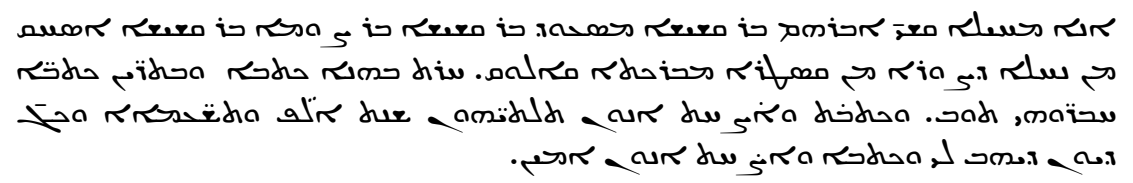

"I, the infirm elder Abraham, son of elder Mas'ūd, son of elder Bar-Ṣawma, son of elder Isaac, of the valley of Tyre and the blessed castle Qālūq, inspected this volume along with two others joined with it, and copied the three in the Hellenic year 1923 (I6I2 after Jesus Christ) (for elder 'Abd al-Ahad), 53 who gave them to me to transcribe, amen.”

53 These words may be supplied from the Arabic note transcribed below. 
The same note is then transcribed in Arabic in the following way:

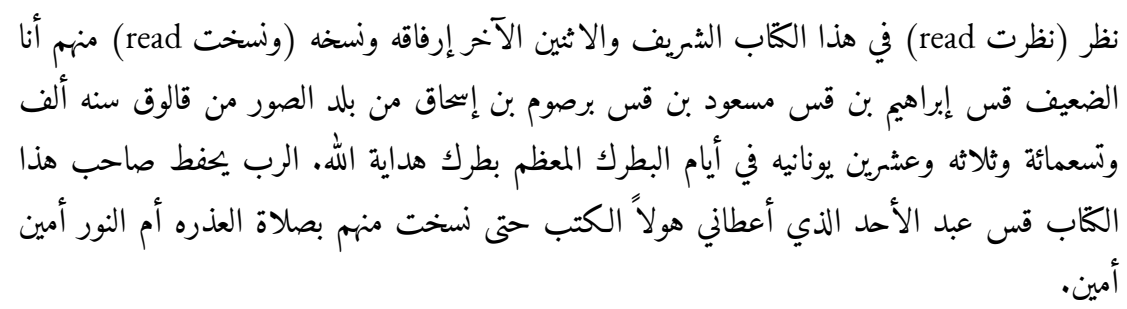

"I, infirm elder Abraham, son of elder Mas'ūd, son of elder Bar-Ṣawma, son of elder Isaac, of the land of Tyre, of Qālūq inspected this noble book and two others joined to it, and copied them in the Hellenic year 1923, in the days of the great patriarch Patriarch Hidāyatullah. ${ }^{54}$ May the Lord preserve the owner of this book, elder 'Abd al-Ahad, who gave to me these books so that I could transcribe them, by the prayer of the virgin mother of the Light, amen, amen.”

Another brief note informs us that the elder 'Abd al-Ahad bar Muqaddasī Yūsufs̃āh received ordination as a priest on the twenty-ninth day of the month of Tamuz in the Hellenic year I92I.

\section{Manuscript B}

A manuscript written in 'Nestorian' characters on 554 paper folios (0.3I x 0.2I), with the shelfmark Ioo in the Royal Library of Berlin; see Sachau, Verzeichness der syr. Handschriften zu Berlin, 356. It consists of old and new fragments and is divided into two volumes; the first part contains letters àlap-tét, and the second part contains the rest of the letters. The older fragments, which we have referred to the sixteenth century, Sachau preferred to assign to the seventeenth or eighteenth century (see Verzeichness der syr. Handschr., 356); folios 83-88, 90-99, IOI-II8, I20-139, I4I, I42, I47-I59, I62-I85, I87-I9I, 218-225, 242-27I, 288, 289, 340-350, 367-545 make up the older part, which is written in continuous script, except for folios $218-405$, which are written in two columns. The more recent folios were written from another copy in the year 1883 to complete the manuscript; they abound in mistakes, cf. Rahls, Göttingen gelebrte Anzeigen, 1893, 984 .

54 Perhaps better Hadiyat-Allah, that is "Gift of God," in French Dieudonné. It refers to the patriarch of the 'Jacobites'. 
The Arabic glosses are almost always written in Syriac script. At the beginning Bar Bahlul's Syriac and Arabic prefaces are found.

At the end of the verso of folio 554 it reads:

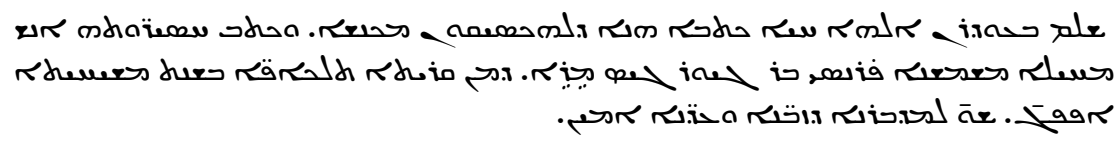

"This book of the compiled lexicon is complete, by the power of the living God, the lacking parts of which were re-written by a weak man, Pransi the deacon, son of George Mere, of the village of Tel-Kepe, in the Christian year I883. Glory to the Director of the times and ages, amen.”

\section{Mixed manuscripts}

Manuscript A, of London, kept in the British Museum under the shelfmark no. 244I Orient. Written on 400 paper folios (0.34 x 0.24), in two columns, in Garšuni, in the year 1878 . The incipit carried the name of Bar 'Ali, which was then erased and replaced with Bar Bahlul's name. It contains the preface to Bar 'Ali's lexicon.

After the publication of our edition the British Museum acquired three other manuscripts, which we have not seen; here we shall give their descriptions from the catalogue recently collected by G. Margoliouth, Descriptive list of Syriac and Karshuni mss. in the British Museum acquired since 1873, London, I899:

P. 30. "Or. 4097. A Syriac and Arabic lexicon (the Arabic taking the Karshuni form) compiled from the lexicon of Bar Bahlul by the Maphrian Simeon al-T urani. It is stated in the colophon (fol. 137 b) that the compiler omitted the Greek words and only retained the Syriac ones; but this principle has not been consistently followed in the work itself. Paper, foll. 137. Sm. folio. Dated A. D. I886.”

P. 30. "Or. 4098. The Syriac and Arabic Lexicon of Hasan bar Bahlul. Paper, foll. 394. Folio. Dated A. D. I883.”

P. 34. "Or. 4406. The Syriac and Arabic Lexicon of Hasan bar Bahlul. Paper, foll. 340. Folio. Dated A. Gr. 2196 (A. D. I885).

Manuscript L is kept in the University library of Leipzig, and was formerly part of the library of Prof. Sachau; 248 paper folios (0.33 x 0.23), of which the lexicon occupies 227. It was written in the year I88I by 'Abd al-'Azīz, son of George the elder, of the 'Jacobite' village Bašiqa (in Țur-'Abdin). In the incipit, the name of Bar 'Ali is erased, and the name of Bar Bahlul is written in its place. It carries Bar 'Ali's Syriac preface with an Arabic translation. 
Manuscript $\mathrm{B} b$ is kept in the Royal library of Berlin, with the shelfmark 229 ( $\mathrm{Sa}$ chau 194); 295 paper folios (0.32 x 0.22), in two columns. It was completed on the sixth day of November, I882, by the same 'Abd al-'Aziz. The incipit gives the name of Bar 'Ali, but Bar 'Ali's preface is lacking. See Sachau, Verzeichness der syr. Handschr. zu Berlin, 7 II.

Manuscript B $b b$ is kept in the same library of Berlin, with the shelfmark 228 (Sachau 305, not 395, as was erroneously printed in the preface to the first fascicule, p. ii above), 508 folios (0.33 x 0.23). It was completed on the seventh day of June, I839, by David the elder. But Sachau has claimed that David the elder was (in fact) two scribes, the later of whom did not live much after the earlier. Arabic glosses are written in Syriac script. Syriac and Arabic versions of Bar 'Ali's preface (are given) at the beginning, as in manuscript L, but the short note carries the name of David the elder, where the name Abraham is written in manuscript L and other manuscripts (cf. above, ix, 1. 24). See Sachau, Verzeichness der syr. Handschr. zu Berlin, 7ıо.

Manuscript Bbbb is kept in the same library, with the shelfmark 230 (Sachau I7I); 342 folios ( $0.33 \times 0.23$ ), in two columns, written in year 1883 by the 'Abd al-'Aziz mentioned above (see manuscripts $\mathrm{L}$ and $\mathrm{B} b$ ). It contains no preface. See Sachau, Verzeichness der syr. Handschr. zu Berlin, 712.

The copies which Bernstein arranged to be prepared from several manuscripts kept in European libraries were deposited in the Royal library of Berlin with the shelfmark 227 (Ms. Orient., 542-544), as we said in the preface to the first fascicule, page iv above. These include: $\mathrm{A}$, a copy of manuscript $\mathrm{H}$, containing Ioor pages, copied in the year 1836 , (pages $873-882$ of the manuscript being omitted; B, a copy of the first half of manuscript M (letters $\lrcorner-\Omega$ ), with the additional collation of manuscript $F$ in green and manuscript $\mathrm{C}$ in red, containing 7or pages, in two columns, written in the years 1836 and 1837 ; $C$, with parts of the same manuscript F (letters $\boldsymbol{\phi}, \boldsymbol{\Omega}, \boldsymbol{\Sigma}$, and $\boldsymbol{\text { r }}$ ), written in II9 pages. Cf. Bernstein, Z. D. M. G., II, 37I; Sachau, Verzeichness der syr. Handschr. zu Berlin, 709 .

\section{ON THE SYRIAC AND ARABIC PREFACES OF BAR BAHLUL}

It is clear from the descriptions given in the previous section of the manuscripts of the lexicon available to us that Bar Bahlul's prefaces are only found in manuscripts BHRSs. Having collated these manuscripts with one another, we may relate that the texts (of these prefaces) are printed at the beginning of the edition (col. I-4), the Latin translations of which are given on pages xi-xii of this introduction, above. 